\title{
Aa. Vv., «Le Courrier balzacien», n. 1
}

\section{Marco Stupazzoni}

\section{(2) OpenEdition}

\section{Journals}

\section{Edizione digitale}

URL: http://journals.openedition.org/studifrancesi/8973

DOI: 10.4000/studifrancesi.8973

ISSN: 2421-5856

\section{Editore}

Rosenberg \& Sellier

\section{Edizione cartacea}

Data di pubblicazione: 1 octobre 2008

Paginazione: 473

ISSN: 0039-2944

\section{Notizia bibliografica digitale}

Marco Stupazzoni, «Aa. Vv., «Le Courrier balzacien», n. 1», Studi Francesi [Online], 155 (LII | II) | 2008,

online dal 30 novembre 2015, consultato il 12 janvier 2021. URL: http://journals.openedition.org/ studifrancesi/8973 ; DOI: https://doi.org/10.4000/studifrancesi.8973

Questo documento è stato generato automaticamente il 12 janvier 2021.

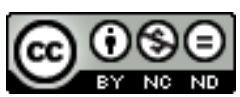

Studi Francesi è distribuita con Licenza Creative Commons Attribuzione - Non commerciale - Non opere derivate 4.0 Internazionale. 


\title{
Aa. Vv., «Le Courrier balzacien», n. 1
}

\author{
Marco Stupazzoni
}

\section{NOTIZIA}

«Le Courrier balzacien», n. 1, 2006, pp. 48.

1 Pubblicato con una nuova veste grafica, questo nuovo numero del «Courrier balzacien» (il primo dell'annata 2006) contiene un'ampia selezione delle produzioni artistiche presentate in occasione della mostra Balzac. Version Arts Appliqués (Paris, maison de Balzac, 21 settembre-17 dicembre 2006) dagli allievi dell'École nationale supérieure des arts appliqués et des métiers d'art Olivier de Serres sotto la direzione di Frédéric Siard. Riconosciuto e posto in primo piano il ruolo fondamentale della descrizione nell'opera di Balzac, l'obiettivo principale di questo progetto è quello - scrive Yves GAGNEUX (De la description à la création de l'ENSAAMA, Olivier de Serres face à Balzac, pp.4-10) - di "confronter la littérature et les connaissances historiques pour construire un projet artistique singulier» (p.4). Questa serie di descrizioni estratte da racconti e romanzi della Comédie humaine (La Fille aux yeux d'or, La Vieille Fille, La Maison du chat-qui-pelote, Eugénie Grandet, La Bourse, Le Chef-d'oeuvre inconnu, La Peau de chagrin, La Recherche de l'Absolu, Le Père Goriot, Béatrix), la cui lettura ha fornito in molti casi una «interprétation beaucoup plus poussée du texte» (p. 10), ha consentito ad ogni artista - osserva F. SIARD (Reconstituer Balzac, illustration et défense d'un enseignement artistique, pp.14-25) - di «découvrir et expérimenter des méthodes d'investigation et d'analyse propres aux archéologues et aux historiens de l'art» (p. 14). 